\title{
Cytotoxic T lymphocyte antigen-4 (CTLA-4) A49G polymorphism and autoimmune blood diseases
}

\author{
Sitotoksik T lenfosit antijen-4 (CTLA-4) A49G polimorfizmi ve otoimmün kan \\ hastalıkları
}

Faruk Aktürk1, Veysel Sabri Hançer², Reyhan Küçükkaya ${ }^{3}$

${ }^{1}$ Division of Hematology, Department of Internal Medicine, Istanbul University, Istanbul Faculty of Medicine, Istanbul, Turkey 2Department of Medical Biology and Genetics, Istanbul Bilim University, Faculty of Medicine, istanbul, Turkey

${ }^{3}$ Department of Internal Medicine, Istanbul Bilim University, Faculty of Medicine, istanbul, Turkey

\begin{abstract}
Objective: The cytotoxic T lymphocyte associated antigen-4 (CTLA-4) is expressed on T lymphocytes, and inhibits the T-cell responses. In animal models, it has been shown that complete CTLA-4 deficiency was lethal due to massive infiltration of tissues by polyclonally proliferating lymphocytes. CTLA-4 A49G polymorphism, which has been suggested to reduce the inhibitory function of the CTLA-4 molecule, was found to be associated with various autoimmune diseases in recent studies.

Material and Methods: In this study, we evaluated the frequency of CTLA-4 A49G polymorphism in 46 patients with autoimmune hemolytic anemia (AlHA), 62 patients with immune thrombocytopenic purpura (ITP), and 150 healthy individuals.

Results: Allele frequencies and genotype distributions were similar in both ITP and AlHA patients compared to healthy individuals. In subgroup analysis, however, we found that in chronic lymphocytic leukemia (CLL) patients with AlHA $(n=4)$, all patients had CTLA-4 A49G polymorphism (3 had AG, 1 had GG). There was no significant statistical association between $G$ allele and systemic lupus erythematosus (SLE) or AlHA.

Conclusion: These data suggest that CTLA-4 A49G polymorphism does not contribute to the pathogenesis of lymphoproliferative diseases itself, nor does it increase the risk of autoimmune complications in patients with lymphoproliferative disease. (Turk J Hematol 2010; 27: 78-81)

Key words: Cytotoxic T lymphocyte antigen-4 (CTLA-4), A49G polymorphism, autoimmunity, idiopathic thrombocytopenic purpura, autoimmune hemolytic anemia, chronic lymphocytic leukemia

Received: December 26, 2008

Accepted: February 22, 2010

Özet

Amaç: Sitotoksik T lenfosit antijen-4 (CTLA-4) ifadesi T lenfositlerde gerçekleşir ve T hücre cevabını engeller. Hayvan modellerinde CTLA-4 yokluğunun, dokuların poliklonal çoğalan lenfositler tarafından yoğun infiltrasyonu nedeni ile, ölümcül olduğu gösterilmiştir. Farklı otoimmün hastalıklar ile ilişkilendirilmiş CTLA-4 A49G polimorfizminin, CTLA-4 molekülünün inhibitör fonksiyonunu azalttığı düşünülmektedir.

Yöntem ve Gereçler: Bu çalışmada otoimmun hemolitik anemi (OIHA) hastası 46 kişi, immun trombositopenik purpura (ITP) hastası 62 kişi ve 150 sağlıklı kontrol bireyinde CTLA-4 A49G polimorfizmi çalışımıştır.
\end{abstract}


Bulgular: ITP ve OIHA hastalarından oluşan iki grupta da sağlıkı kontrol bireyleri ile karşılaştırıldığında benzer allel frekansları ve genotip dağılımları saptanmıştır. Alt grup analizi gerçekleştirildiğinde ise hem OlHA hem de KLL hastalığına sahip 4 bireyin hepsinin polimorfizme sahip olduğu gösterilmiştir (3 AG, 1 GG). Risk alleli olan G OIHA, ITP ve kontrol grubunda incelendiğinde istatistik olarak anlamlı bir farklılık saptanmamıştır.

Sonuç: Bu verilerin ışı̆̆ında CTLA-4 A49G polimorfizminin lenfoproliferatif hastalıkların patogenezine bir katkısının olmadığı veya lenfoproliferatif hastalığa sahip bireylerde otoimmün komplikasyonların gelişmesi açısından risk oluşturmadığı sonucuna varımıştır. (Turk J Hematol 2009; 27: 78-81)

Anahtar kelimeler: Sitotoksik T lenfosit antijen-4 (CTLA-4), A49G polimorfizmi, otoimmünite, idiopatik trombositopenik purpura, otoimmün hemolitik anemi, kronik lenfositik lösemi

\section{Introduction}

Autoimmune disorders are the result of disturbed immune tolerance to self-antigens. After the presentation of an antigen in conjunction with HLA molecules on the surface of an antigen-presenting cell to a specific T-cell receptor (TCR), costimulatory signals are required for the T-cell responses [1]. A number of co-stimulatory molecules are present on the T-cell membrane, which may have stimulatory or inhibitory effects on $\mathrm{T}$ lymphocytes. The cytotoxic $\mathrm{T}$ lymphocyte associated antigen-4 (CTLA-4) is expressed on T lymphocytes and inhibits the T-cell responses [2]. Mechanisms of down-regulation of T-cell immunogenic response by CTLA-4 may be due to competitive antagonism with CD28, increment in TCR stimulation threshold, and limitation of T-cell division capacity and activation of cell cycle arrest of T-cells after antigenic stimulation [2]. In animal models, it has been shown that complete CTLA-4 deficiency was lethal due to severe lymphoproliferative disorders with massive infiltration of tissues by polyclonally proliferating lymphocytes [3]. Blocking the CTLA-4/B7 interaction by monoclonal antibodies results in an increase in antigen-specific T-cell proliferation, whereas enhancing the inhibitory function of CTLA-4 suppresses $T$-cell responses $[1,2]$. These findings provide strong evidence that CTLA-4 has a crucial role in the negative regulation of $\mathrm{T}$-cell responses.

The CTLA-4 gene is located on chromosome 2 (2q33). Several polymorphisms were identified on the CTLA-4 gene [4]. The A49G polymorphism in exon 1 of the CTLA-4 gene is especially important because it alters the structure of the CTLA-4 protein by causing Thr17Ala amino acid substitution [5]. It has been suggested that this polymorphism reduces the inhibitory function of CTLA-4 [2]. In recent studies, the CTLA-4 A49G polymorphism was found to be associated with autoimmune diseases such as insulin-dependent diabetes, rheumatoid arthritis, systemic lupus erythematosus (SLE), multiple sclerosis, primary biliary cirrhosis, Hashimoto's thyroiditis, and Graves' disease $[1,2,4,6]$. In this study, we evaluated the frequency of the CTLA-4 A49G polymorphism in patients with autoimmune hemolytic anemia (AlHA) and autoimmune thrombocytopenic purpura (ITP).

\section{Materials and Methods}

Participants: The present study was approved by the local ethics committee (Istanbul Faculty of Medicine) and all participants gave informed consent. Patients were selected from cases admitted to the Hematology Division of the Istanbul Faculty of Medicine from May 2003 to June 2006. One hundred and fifty healthy Turkish subjects, 46 patients with AlHA and 62 patients with ITP were included in our study. ITP and AlHA patients were diagnosed by standard methods and were being followed by the Hematology Department.

In the AlHA group, median age was 53 (28-66) and male to female ratio was 13/33. Fourteen AlHA patients also had SLE, 4 had chronic lymphocytic leukemia (CLL), 2 had Evans's syndrome, and 2 had autoimmune diseases other than SLE (autoimmune thyroiditis and autoimmune hepatitis).

In the ITP group ( $n=62)$, median age was 41 (18-56) and male to female ratio was $17 / 45$. Thirty-six patients had primary ITP. Twenty-six patients in the ITP group had antiphospholipid antibodies (aPLA), and 12 of those patients were diagnosed as definite antiphospholipid syndrome (with thrombosis and/or pregnancy morbidity). Fourteen ITP patients had only persistent aPLA-positivity.

In the healthy control group $(n=150)$, median age was 38 years (18-55), and male to female ratio was 67/83.

Methods: Genomic DNA was isolated from peripheral venous blood samples using high pure polymerase chain reaction (PCR) template preparation kit (Roche Diagnostics). For the amplification of exon 1 to show CTLA-4 A49G polymorphism, 5'-GCTCTACTCCTGAAGACCT-3' and 5'-AGTCTCACTCACTCACПTGCAG-3' primers were used. Amplified DNA samples were digested by $B b v$ I restriction endonuclease enzyme (New England Biolabs, Beverly, MA). Amplified fragment (162 bp) analyzed on 3.5\% agarose gel was stained by ethidium bromide. The allele $A$ was not cut by the enzyme and so left $162 \mathrm{bp}$; on the contrary, G allele was cut into two DNA fragments 88 and 74 bp long [4].

Statistical Analysis: Statistical analysis was performed using chi-square and Fisher's exact tests at 'Graphpad for Windows Version 3.0'. P values $<0.05$ were accepted as statistically significant. Results of the statistical analysis of comparisons of the allele frequencies are shown in Table 1.

\section{Results}

Healthy Controls: One hundred and fifty healthy subjects were investigated in terms of CTLA-4 A49G polymorphism. 
Table 1. Patient and control genotype and allele frequencies for the CTLA-4 A49G polymorphism

\begin{tabular}{|c|c|c|c|c|c|c|c|c|c|}
\hline & $n$ & AA & AG & GG & Allele A & Allele $\mathbf{G}$ & $p$ (vs *) & OR & $95 \% \mathrm{Cl}$ \\
\hline Total AlHA & 46 & 21 & 21 & 4 & 63 & 29 & 0.643 & 0.85 & $0.517-1.425$ \\
\hline Primary AlHA & 28 & 15 & 11 & 2 & 41 & 15 & 0.874 & 1.08 & $0.568-2.055$ \\
\hline SLE+AlHA & 14 & 6 & 7 & 1 & 19 & 9 & 0.660 & 0.83 & $0.363-1.918$ \\
\hline CLL+AlHA & 4 & 0 & 3 & 1 & 3 & 5 & 0.049 & 0.23 & $0.055-1.015$ \\
\hline Total ITP & 62 & 38 & 21 & 3 & 97 & 27 & 0.183 & 1.42 & $0.865-2.333$ \\
\hline Primary ITP & 36 & 23 & 13 & 0 & 59 & 13 & 0,1004 & 1.79 & $0.935-3.441$ \\
\hline aPLA+ ITP & 26 & 15 & 8 & 3 & 38 & 14 & 1.000 & 1.07 & $0.553-2.081$ \\
\hline Healthy individuals* & 150 & 72 & 71 & 7 & 215 & 85 & - & - & - \\
\hline
\end{tabular}

AlHA: Autoimmune hemolytic anemia; SLE: Systemic lupus erythematosus; CLL: Chronic lymphocytic leukemia; ITP: Immune thrombocytopenic purpura; aPLA: Antiphospholipid antibodies; OR: Odds ratio; Cl: Confidence interval

Genetic variation was distributed according to Hardy-Weinberg equilibrium. Genotype frequencies were $48 \%$ for AA, $47.3 \%$ for AG and $4.7 \%$ for GG. A-allele frequency was $71.6 \%$ and G-allele frequency was $28.4 \%$ (Table 1). There was no statistical difference between genders and allele frequencies in the healthy control group.

AlHA Group: Twenty-one patients had AA (45.6\%), 21 had AG (45.6\%), and 4 had GG (8.8\%) genotype in this group. A-allele frequency was $68.4 \%$ and G-allele frequency was $31.6 \%$, which was similar to healthy controls. In sub-group analysis, in a small group of patients with CLL and AlHA $(n=4)$, all patients were found to have CTLA-4 A49G polymorphism (3 had AG, 1 had GG) (Table 1). When we statistically compared the risk allele $\mathrm{G}$ in the AlHA and control groups, there was no statistical difference $(p=0.643$; odds ratio [OR]: 0.858; 95\% confidence interval [Cl]: 0.8658-2.33). In sub-group analysis, we found no difference between patients and controls for the risk allele $\mathrm{G}$ (Table 1).

ITP Group: Thirty-eight had AA (61.3\%), 21 had AG (33.9\%), and 3 had GG (4.8\%) genotype in this group. A-allele frequency was $78.4 \%$ and G-allele frequency was $21.6 \%$. There was no statistical difference between the ITP group and healthy control group for the risk allele. In sub-group analysis, we similarly found no difference between ITP patients and controls for the risk allele $\mathrm{G}$.

\section{Discussion}

The role of the CTLA-4 A49G polymorphism in the development of autoimmune diseases is not well understood. Since CTLA-4 controls the amplitude of immune response and peripheral tolerance, this polymorphism could have an impact on autoimmunity in some way. The CTLA-4 A49G polymorphism may result in susceptibility to autoimmune disease $[1,2,6,7]$.

The role of the CTLA-4 A49G polymorphism in the development of autoimmune blood diseases such as ITP and AlHA is not clear. In the only published study, which was done by Pavkovic et al. [5], it was shown that the CTLA-4 A49G polymorphism was significantly higher in patients with AlHA, but no association was found in patients with ITP. They also showed that the G-allele frequency was highest among CLL patients who had developed AlHA. In that study, $60 \%$ of the AlHA cases were patients with CLL. Our study is the second study investigating the role of the CTLA-4 A49G polymorphism in patients with ITP and AlHA. Although we could not demonstrate an association between autoimmune blood diseases and the CTLA-4 A49G polymorphism, we found very interesting results in the CLL+AlHA subgroup, as in Pavkovic's study. In our study, all CLL patients who had AlHA $(n=4)$ were found to have $G$ allele (3 had AG, 1 had GG). With the knowledge of the development of fatal lymphoproliferative disease in CTLA-4-deficient mice, these data suggest that the CTLA-4 A49G polymorphism may contribute to the pathogenesis of the lymphoproliferative diseases itself, or may increase the risk of autoimmune complications in patients with lymphoproliferative diseases. In a metaanalysis study, Lee et al. [6] demonstrated a significant statistical association between the A49G polymorphism and SLE susceptibility. Their meta-analysis did not show a significant association of other polymorphisms of CTLA-4 with SLE. Though the estimated ORs from the race-specific analysis were very similar, a statistically significant SLE association was found with Asians only $(n=522)$. Similarly, in our study, there was no association between the A49G polymorphism and SLE in the Caucasian population based on this meta-analysis. When we statistically compared groups, there was no association between the AlHA and control group. In contrast to Lee et al. [6], in the present study, our findings demonstrated that there was no significant statistical association between $\mathrm{G}$ allele and SLE. Similar findings were seen for ITP (Table 1).

In conclusion, our results showed that there is no association between the A49G polymorphism of the CTLA-4 gene and AlHA or ITP disease. Further genetic and clinical studies are required to understand the exact role of the CTLA-4 A49G polymorphism in the development of autoimmune and lymphoproliferative diseases.

\section{Conflict of interest}

No author of this paper has a conflict of interest, including specific financial interests, relationships, and/or affiliations relevant to the subject matter or materials included in this manuscript. 


\section{References}

1. Chambers CA, Kuhns MS, Egen JG, Allison JP. CTLA-4 mediated inhibition in regulation of $T$ cell responses: mechanisms and manipulation in tumor immunotherapy. Annu Rev Immunol 2001;19:565-94.

2. Teft WA, Kirchhof MG, Madrenas J. A molecular perspective of CTLA-4 function. Annu Rev Immunol 2006;24:65-97.

3. Waterhouse $P$, Penninger JM, Timms E, Wakeham A, Shahinian A, Lee KP, Thompson CB, Griesser H, Mak TW. Lymphoproliferative disorders with early lethality in mice deficient in CTLA-4. Science 1995;270:985-8.
4. Sahin M, Erdogan MF, Erdogan G. Cytotoxic T lymphocyteassociated molecule-4 polymorphisms in Turkish Graves' disease patients and association with probability of remission after antithyroid therapy. Eur J Intern Med 2005;16:352-5.

5. Pavkovic M, Georgievski B, Cevreska L, Spiroski M, Efremov DG. CTLA-4 exon 1 polymorphism in patients with autoimmune blood disorders. Am J Hematol 2003;72:147-9.

6. Lee YH, Harley JB, Nath SK. CTLA-4 polymorphisms and systemic lupus erythematosus (SLE): a meta-analysis. Hum Genet 2005;116:361-7.

7. Dallos T, Kovacs L. CTLA-4 and the genetic predisposition on autoimmunity. Bratisl Lek Listy 2005;106:55-62. 